\title{
Article \\ Climatic Alterations Influence Bacterial Growth, Biofilm Production and Antimicrobial Resistance Profiles in Aeromonas spp.
}

\author{
Miguel L. Grilo 1,2,*, Ana Pereira ${ }^{2}$, Carla Sousa-Santos ${ }^{2} \mathbb{D}$, Joana I. Robalo ${ }^{2}$ and Manuela Oliveira $1, *(\mathbb{D}$ \\ 1 Centro de Investigação Interdisciplinar em Sanidade Animal (CIISA), Faculdade de Medicina Veterinária, \\ Universidade de Lisboa, 1300-477 Lisbon, Portugal \\ 2 Marine and Environmental Sciences Centre (MARE), Instituto Universitário de Ciências Psicológicas, \\ Sociais e da Vida (ISPA), 1100-304 Lisbon, Portugal; ana_pereira@ispa.pt (A.P.); carla.santos@ispa.pt (C.S.-S.); \\ jrobalo@ispa.pt (J.I.R.) \\ * Correspondence: miguelgrilo@fmv.ulisboa.pt (M.L.G.); moliveira@fmv.ulisboa.pt (M.O.)
}

check for

updates

Citation: Grilo, M.L.; Pereira, A.; Sousa-Santos, C.; Robalo, J.I.; Oliveira, M. Climatic Alterations Influence Bacterial Growth, Biofilm Production and Antimicrobial Resistance Profiles in Aeromonas spp. Antibiotics 2021, 10, 1008. https://doi.org/10.3390/ antibiotics 10081008

Academic Editors: Carlos M. Franco and Marc Maresca

Received: 14 July 2021

Accepted: 17 August 2021

Published: 20 August 2021

Publisher's Note: MDPI stays neutral with regard to jurisdictional claims in published maps and institutional affiliations.

Copyright: (c) 2021 by the authors. Licensee MDPI, Basel, Switzerland. This article is an open access article distributed under the terms and conditions of the Creative Commons Attribution (CC BY) license (https:/ / creativecommons.org/licenses/by/ $4.0 /)$.

\begin{abstract}
Climate change is expected to create environmental disruptions that will impact a wide array of biota. Projections for freshwater ecosystems include severe alterations with gradients across geographical areas. Life traits in bacteria are modulated by environmental parameters, but there is still uncertainty regarding bacterial responses to changes caused by climatic alterations. In this study, we used a river water microcosm model to evaluate how Aeromonas spp., an important pathogenic and zoonotic genus ubiquitary in aquatic ecosystems, responds to environmental variations of temperature and $\mathrm{pH}$ as expected by future projections. Namely, we evaluated bacterial growth, biofilm production and antimicrobial resistance profiles of Aeromonas species in pure and mixed cultures. Biofilm production was significantly influenced by temperature and culture, while temperature and $\mathrm{pH}$ affected bacterial growth. Reversion of antimicrobial susceptibility status occurred in the majority of strains and tested antimicrobial compounds, with several combinations of temperature and $\mathrm{pH}$ contributing to this effect. Current results highlight the consequences that bacterial genus such as Aeromonas will experience with climatic alterations, specifically how their proliferation and virulence and phenotypic resistance expression will be modulated. Such information is fundamental to predict and prevent future outbreaks and deleterious effects that these bacterial species might have in human and animal populations.
\end{abstract}

Keywords: microcosm; Aeromonas; climate change; temperature; $\mathrm{pH}$; biofilm; antimicrobial resistance; water

\section{Introduction}

Environmental conditions are a major driver of bacterial activity and can shape the expression of several metabolic pathways [1,2]. Namely, such parameters have the potential to influence bacterial virulence (e.g., biofilm formation) and antibiotic resistance signatures $[3,4]$.

Climatic scenarios, as predicted by simulation methodologies based on different levels of emissions, are projected to significantly differ from currently observed meteorological conditions [5]. Regarding aquatic ecosystems, and particularly in freshwater habitats, various environmental parameters are expected to be altered in the coming years. Water temperature, directly influenced by air temperature, is expected to rise across different habitats [6]. Additionally, the occurrence of heatwaves will likely increase, resulting in extended periods of drought associated with a low flow of freshwater systems, a decrease in water level and in dissolved oxygen concentrations [7-9]. Consequently, reduced dilution of freshwater streams will also affect ion balance levels [10,11]. These biotic changes will impact ecosystem dynamics and promote disruptions in species equilibrium $[9,12]$. All of 
these events are expected to significantly decrease freshwater's quality [13]. Ultimately, these changes compromise future water availability, freshwater ecosystems' structure and populations' sustainability [14-16].

Natural aquatic ecosystems, often the last destination of terrestrial runoffs, are known reservoirs of both antimicrobial resistance and bacterial virulence determinants [17]. The microbiota present there, with or without direct connection with clinical infections, constitute a pool of information to the terrestrial microbiota or can even be disseminated to anthropogenic cycles [18]. This intricate connection between environmental microbiota and bacterial genus with effects at the One Health level stresses the importance of close surveillance of antimicrobial resistance and virulence dynamics in natural habitats in order to prevent epidemic situations both in anthropogenic settings and natural habitats $[19,20]$. Since modeling bacterial responses to changing environmental parameters in natural habitats is challenging, lab simulations-e.g., microcosm assays-are an important tool to predict how microbiota will respond to environmental cues foreseen in climatic predictions [21,22].

We hypothesize that aquatic bacteria's antimicrobial resistance signatures and virulence traits, as well as their growth, may vary with changing environmental conditions. In order to test this, we applied microcosm simulation assays using different water temperatures and $\mathrm{pH}$ values following established emissions scenarios [5] to Aeromonas spp.-a model bacterial genus ubiquitous across different aquatic ecosystems-and evaluated changes in the antimicrobial resistance profile, biofilm production and growth of the isolates under study.

\section{Results}

Biofilm production by each of the Aeromonas strains in pure and mixed culture in the different assays is illustrated in Figure 1. Each strain's response to temperature and $\mathrm{pH}$ was variable between species and within the same species.

When considering results by groups (Aeromonas species individually and mixed cultures), biofilm production in the mixed cultures' wells was significantly lower $(p<0.001)$ than in the other groups. Additionally, water temperature also significantly influenced biofilm production $(p=0.006)$, with isolates exposed to the Fluctuations treatment producing less biofilm (Figure 2). The different $\mathrm{pH}$ conditions tested did not influence biofilm production.

Regarding mixed culture wells, re-isolation and identification of the initial Aeromonas pool added to each well was not possible with several combinations of temperature and $\mathrm{pH}$ treatments. Aeromonas species prevalence at the end of microcosm assays varied across the applied treatments and also between replicates (Figure 3). When evaluating the influence of each individual Aeromonas species present in mixed cultures on the biofilm production, it was observed that no species had a significantly different influence.

Some differences were observed regarding the growth of the isolates during the experiment (Figure 4). Significant differences were recorded between the tested Aeromonas species $(p<0.001)$. A. veronii isolates presented significantly lower concentrations than the other single and mixed cultures, while $A$. hydrophila presented significantly lower concentrations than A. media and mixed cultures. Temperature $(p<0.001)$ and $\mathrm{pH}(p=0.007)$ treatments also influenced bacterial growth. While bacterial growth did not differ between current and fluctuations treatments, it was significantly increased in the RCP 4.5 treatment and decreased in the RCP 8.5 treatment. Bacterial growth was increased in acidic $\mathrm{pH}$ conditions (6.31) when compared to alkaline $\mathrm{pH}$ (8.61). Specific associations were also found between Aeromonas species and $\mathrm{pH}(p=0.002)$ and between temperature and $\mathrm{pH}(p<0.001)$. While $A$. media and mixed cultures presented higher concentrations in water microcosms with $\mathrm{pH}$ 6.31, A. caviae presented higher concentrations at $\mathrm{pH} 8.61$. No differences were observed at $\mathrm{pH}$ 7.61. Regarding the interaction between temperature and $\mathrm{pH}$, concentrations in the $\mathrm{RCP} 4.5$ treatment were higher at $\mathrm{pH}$ 6.31, decreasing until $\mathrm{pH}$ 8.61. For RCP 8.5, higher concentrations were observed at $\mathrm{pH} 8.61$. 

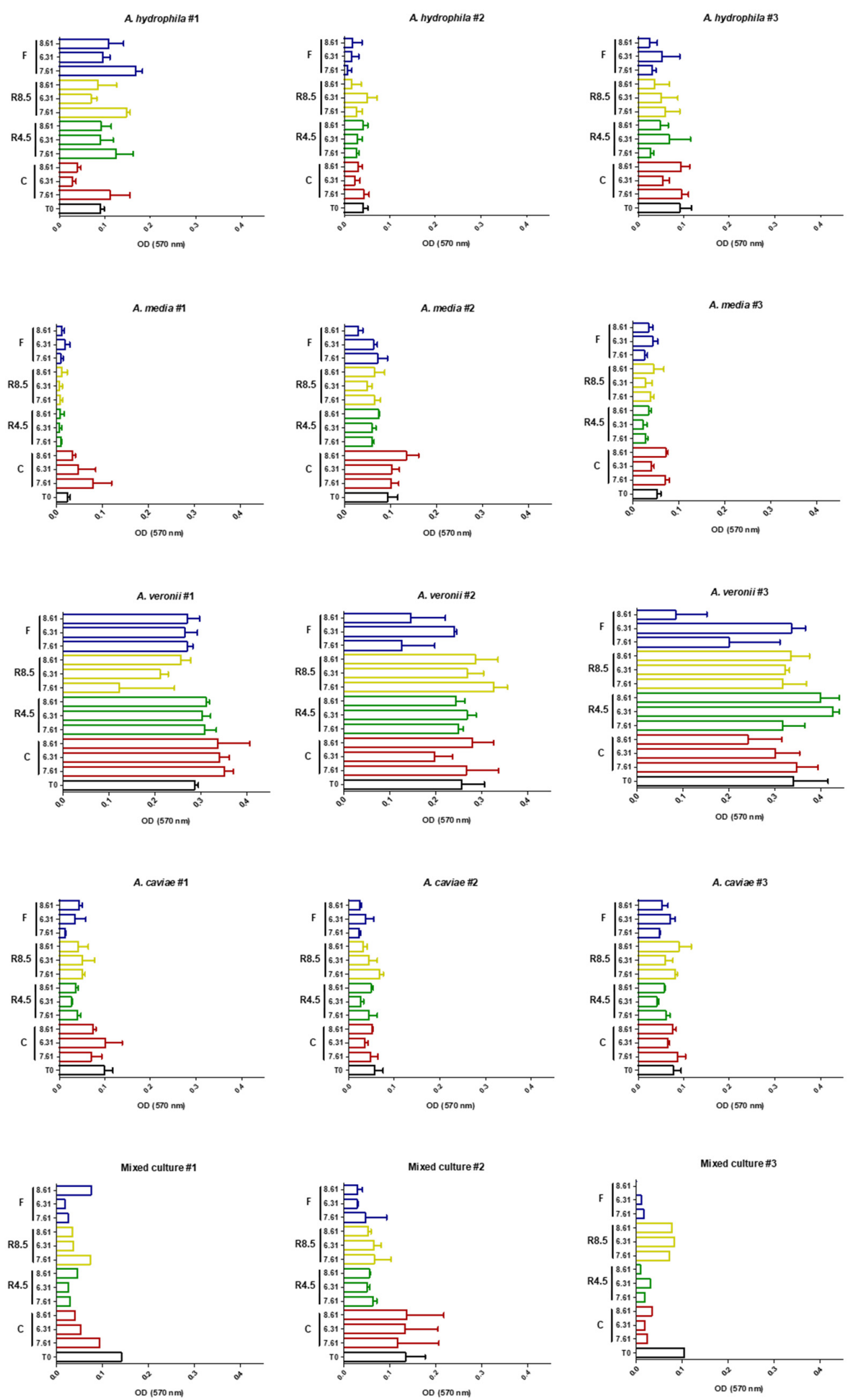

Figure 1. Biofilm production by each strain and mixed culture (mean + SEM). Presented results correspond to values subtracted to each treatment's negative control for normalization. The three replicates' results are presented by strain and mixed cultures, except for replicates where T0 and Current $\mathrm{pH} 7.61$ were considered significantly different $(A$. veronii \#1, Mixed cultures \#1, \#2 and \#3). First column in each graph represents the temperature treatment (C-Current, R4.5-RCP 4.5, R8.5-RCP 8.5, F-Fluctuations) and the second the $\mathrm{pH}$ treatment. OD-Optical density. 
A

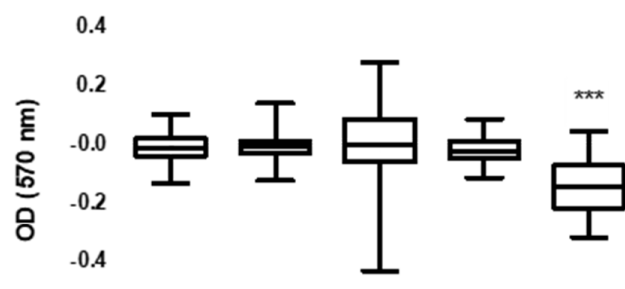

$-0.6$

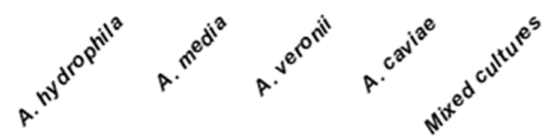

B

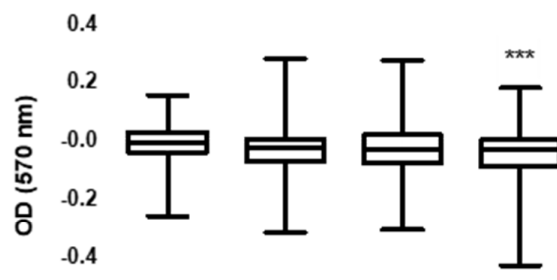

$-0.6$

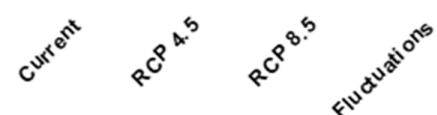

Figure 2. Biofilm production by individual Aeromonas species and mixed cultures (A) and in different water temperature treatment-each treatment includes all strains results. (B). Presented results correspond to values subtracted to each treatment's negative control for normalization and to the corresponding T0 treatment values for comparison. OD—Optical density; ${ }^{* * *} p<0.001$.

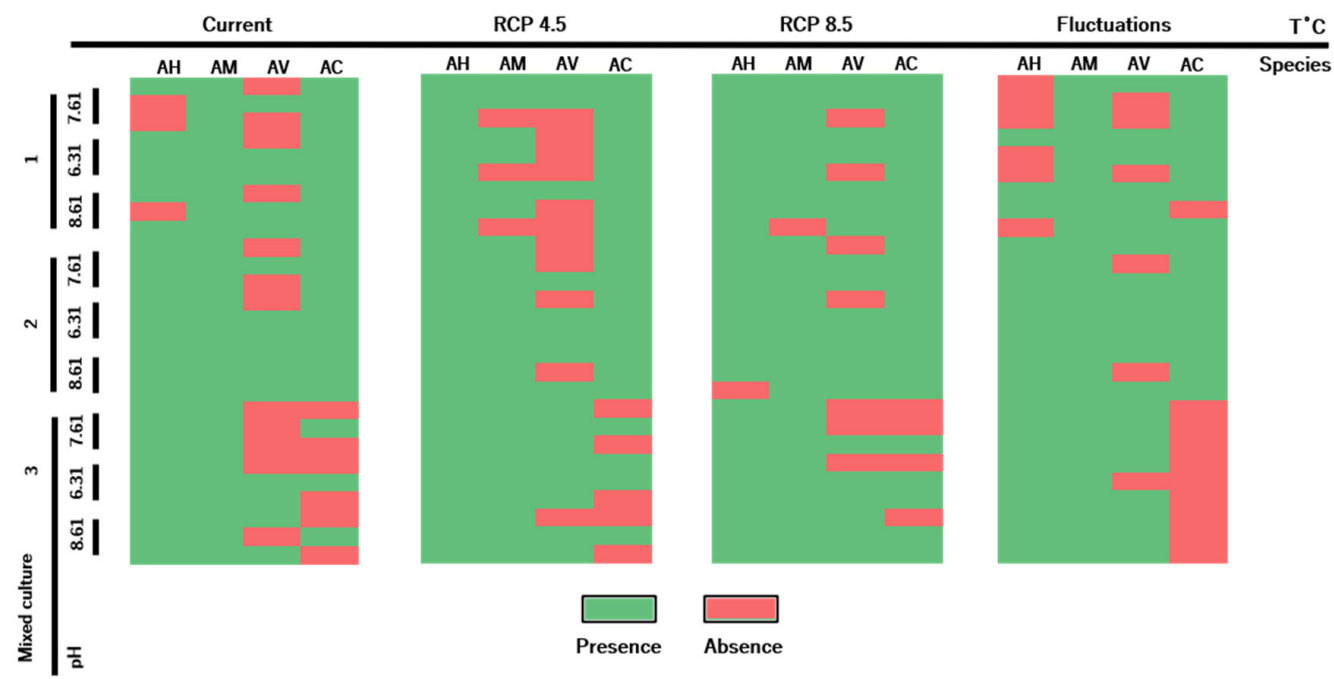

Figure 3. Prevalence of Aeromonas species in the mixed cultured wells after the microcosm assay. Each line corresponds to a distinct replicate belonging to one of the $\mathrm{pH}$ treatments $(7.61,6.31$ and 8.61 ) from the tested mixed cultures (\#1, \#2 and \#3). Each column represents an Aeromonas species (AH-A. hydrophila, AM-A. media, AV-A. veronii, AC-A. caviae) from a specific temperature treatment (Current, RCP 4.5, RCP 8.5 and Fluctuations).

The bacterial concentration was not correlated with biofilm production $\left(r_{s}=0.020\right.$, $p=0.676)$.

Several changes regarding the antimicrobial resistance profile were observed among treatments for the same isolate (Figure 5). Observations between the control treatment (T0, pH 7.61) were similar to results obtained with the current treatment and similar $\mathrm{pH}$ levels. Phenotype variation occurred in a strain-dependent way, and it was specific for each antimicrobial compound tested. For all strains and antibiotics (except $A$. hydrophila and tetracycline), modification of the original susceptibility category occurred with at least one combination of treatments.

In certain situations, reversion of non-wild-type to a wild-type phenotype occurred only with specific combinations of temperature and $\mathrm{pH}$. This is the case of erythromycin susceptibility and A. caviae, $A$. hydrophila and $A$. media. Regarding $A$. caviae and $A$. media, the same treatment (i.e., Current and pH 6.31) caused this phenomenon. In other cases, several combinations resulted in this reversion with no obvious pattern. The opposite was also observed (conversion from wild-type to non-wild-type) among the isolates. Although some treatments seemed to result in this situation more often for some antimicrobial compounds (i.e., RCP 4.5), a high variability was observed. 
A

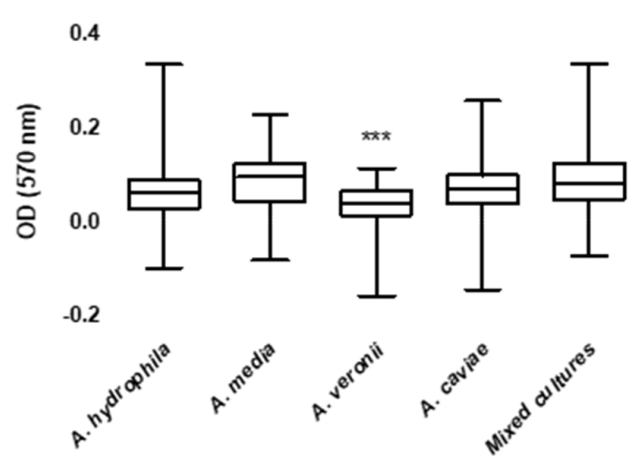

B

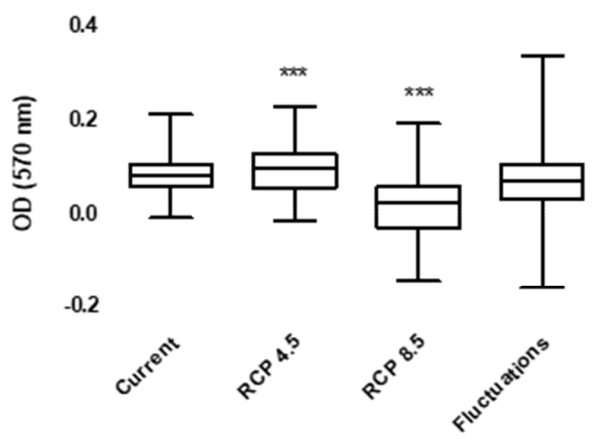

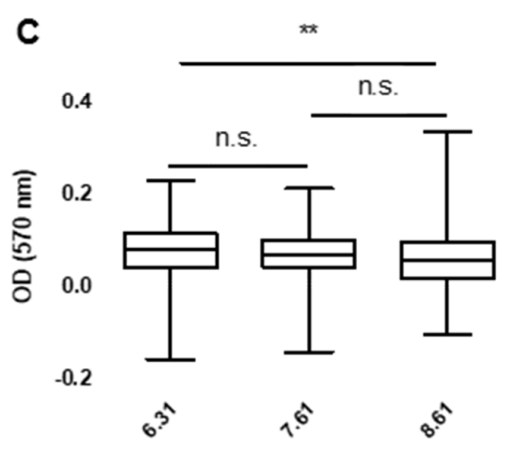

Figure 4. Bacterial concentration by Aeromonas species and mixed cultures (A), by water temperature treatment (B) and by water $\mathrm{pH}$ treatments $(\mathrm{C})$. Presented results correspond to values subtracted to each treatment's negative control for normalization and to the corresponding T0 treatment values for comparison. OD-Optical density. n.s. $p>0.05,{ }^{* *} p<0.01$, *** $p<0.001$.

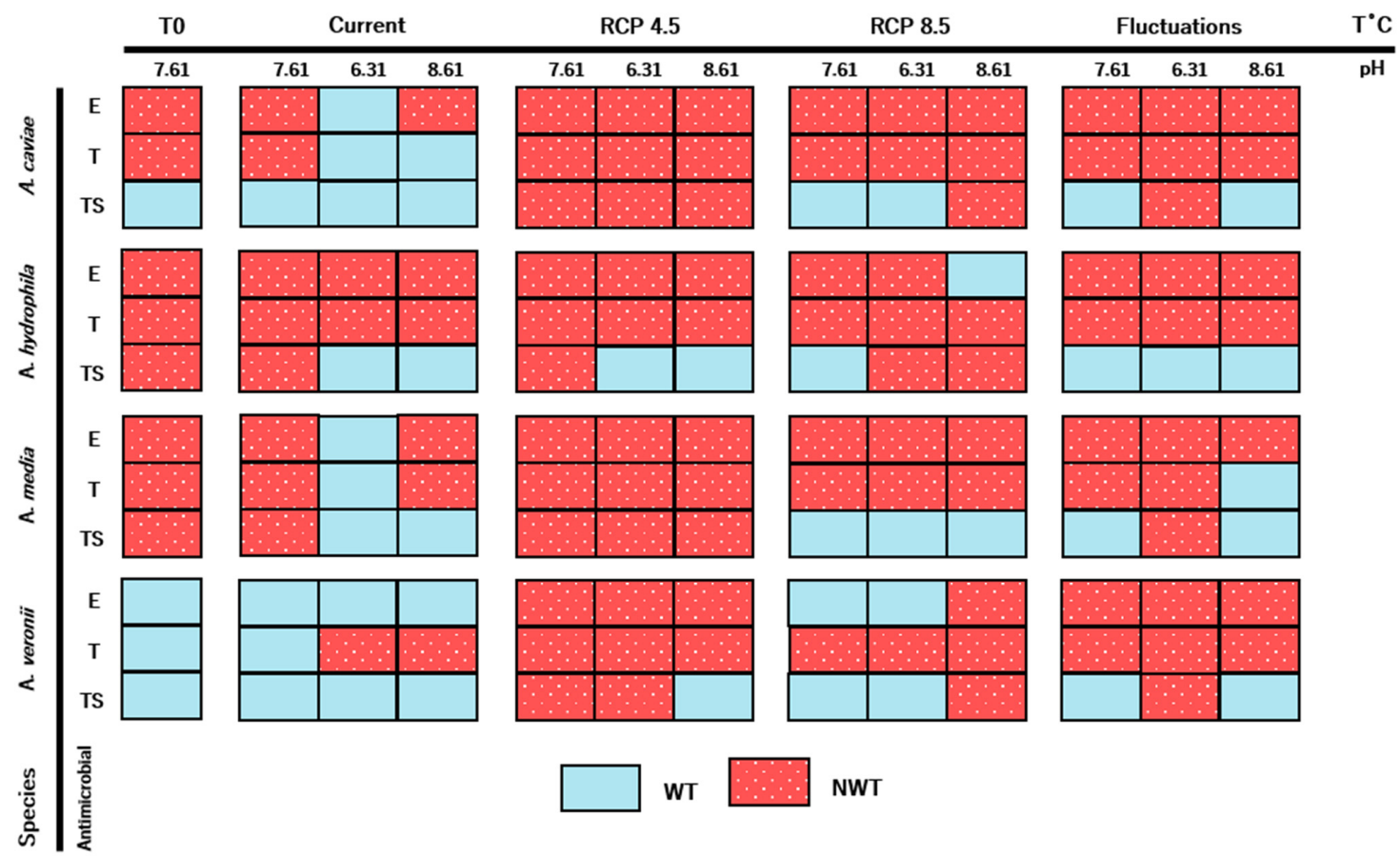

Figure 5. Antimicrobial resistance phenotypes (WT—wild-type, susceptible; NWT—non-wild-type, non-susceptible) of the Aeromonas isolates regarding water temperature and $\mathrm{pH}$ treatments. E-erythromycin, $\mathrm{T}$ - tetracycline, TSsulfamethoxazole/trimethoprim. 


\section{Discussion}

Investigating how bacteria will evolve with environmental cues using natural habitats is a difficult task. Instead, the use of microcosm simulations allows the exploration of such associations, ensuring experimental control and uniformity. This methodology represents a first step in the prediction of transformations to occur in important bacterial genus with an impact at the One Health level, such as Aeromonas spp., and prepare for future outbreaks or phenotypical changes with consequences to public health. In this study, we show that different Aeromonas species adapt their growth, biofilm production and antimicrobial resistance signatures to environmental projections related to climatic alterations (i.e., temperature and $\mathrm{pH}$ ) in water, highlighting the role that future climatic events will have in shaping bacterial activity, as well as virulence and resistance expression. It is noteworthy that, in this study, differences regarding growth, biofilm production and antimicrobial resistance signatures were observed using relatively small temperature and $\mathrm{pH}$ amplitudes, which are more likely to reflect future climatic trends.

\subsection{Biofilm Production}

In general, the studied isolates presented variability in the production of biofilm when exposed to the different temperature and $\mathrm{pH}$ treatments. Although some response patterns were present, the disparity in results between isolates of different species and within the same species highlights the fact that individual characteristics will govern how an isolate will respond to environmental cues; however, significant associations were observed. Mixed cultures produced significantly less biofilm when compared to the Aeromonas species individually. At the end of the microcosm assay, it was not possible to isolate all Aeromonas species in many mixed cultures. Some species absence was more evident than others (e.g., A. caviae in mixed culture \#3 along the various temperature and $\mathrm{pH}$ treatments), although a general pattern was not present. Additionally, and while $\mathrm{pH}$ treatments seem not to influence biofilm production significantly, temperature influenced biofilm production in Aeromonas spp. Namely, isolates exposed to temperature oscillations (i.e., Fluctuations) produced less biofilm. Such biofilm production was not dependent on bacterial concentration. Distinct Aeromonas species display specific preferences regarding environmental parameters [23,24]. Although Aeromonas spp. possess stress response mechanisms to deal with environmental oscillations [25], they still impact several aspects of bacterial life. If the combined temperature and $\mathrm{pH}$ conditions fall within the optimal range for multiplication and virulence expression for each isolate, they will dictate the isolate's competitiveness and ability to survive in an environment composed of multiple species [26,27]. Further, the level of interspecific competition for the limited resources will also hinder each isolate's ability to allocate nutrients to processes such as biofilm production, contrary to what occurs in pure cultures [28]. Finally, environmental oscillations of abiotic factors, such as temperature, will create additional disturbances for the bacterial communities [22] and the overall combination of external stressors with internal competition is likely to impact the final biofilm production.

\subsection{Bacterial Growth}

In this study, a disparity in bacterial growth during the microcosm experiments was observed between the studied species (both in pure culture and in mixed culture). Overall, $A$. veronii isolates displayed a significantly lower growth when compared with other tested groups. Delamare et al. [29] highlighted lower growth patterns by $A$. veronii when compared to other Aeromonas species (i.e., A. hydrophila, A. media and A. caviae). Growth rate variability is a consequence of phenotypic diversity in bacteria [30]. Such variability can be the result of the nutrient uptake rate by the bacterial cell and of the resource's distribution between the processes occurring in the bacterial cell [31]. Aeromonas strains and species growth variability likely reflect different limitations in these processes among the isolates, which can also explain differences observed not only for $A$. veronii but also for $A$. hydrophila. In the mixed cultures group, this pattern was not observed, 
and two hypotheses can be drawn: either other Aeromonas species present in the culture compensated for lower growth rates by $A$. veronii, or interspecific competition eliminated A. veronii presence in the microcosm wells (as stated in Figure 3), facilitating the growth of other species or canceling the growth effect $A$. veronii had in the total growth.

Both changes in water temperature, as well as in the $\mathrm{pH}$ conditions, played a significant role in the growth of Aeromonas spp. Regarding temperature, a biphasic effect was observed: while small increments in water temperature (i.e., RCP 4.5) seem to benefit the Aeromonas species under study, both in pure and in mixed cultures and favor their proliferation; once reaching a certain threshold imposed by higher temperatures (i.e., RCP 8.5), such boosting effect is lost and bacterial growth is lowered. Temperature is a determinant in bacterial growth and Aeromonas typically increase both growth and metabolic activity and decrease lag phase when experiencing higher environmental temperatures [32,33]; however, such growth reaches a plateau with temperature increments and starts to decrease before reaching maximum thermal tolerance [34], highlighting the role of thermal stress as a regulator of bacterial growth. It is noteworthy that, although cultures subjected to the fluctuation treatment experienced similar temperature values, such as the ones in the RCP 8.5 treatment, alternate exposure to higher $\left(24.5^{\circ} \mathrm{C}\right)$ and lower $\left(21^{\circ} \mathrm{C}\right)$ temperature values likely created buffer periods in which bacterial cultures could stabilize and multiplicate.

Regarding $\mathrm{pH}$, the overall growth of Aeromonas spp. was higher in acidic environments when compared to alkaline environments. While some authors found a non-significant effect or a negative effect of $\mathrm{pH}$ on Aeromonas growth [33,35,36], Aeromonas are evolutionarily adapted to low $\mathrm{pH}$ environments, such as the gastrointestinal environment, and have built cellular responses (i.e., protective protein synthesis) that allow for acid tolerance [37]. Additionally, when exposed to acidic environments, the lag phase in Aeromonas is significantly shorter, prompting the beginning of the following growth phases sooner [38]; however, it is likely that different Aeromonas species display specific niche preferences and have evolved towards tolerance in different $\mathrm{pH}$ gradients. This explains why in this study some groups exhibited higher growths in acidic treatments (A. media and mixed cultures), while others performed better in alkaline $\mathrm{pH}$ (A. caviae). Additionally, both temperature and $\mathrm{pH}$ seem to play an interactive role, conditioning higher growth of Aeromonas spp. with specific combinations (i.e., RCP 4.5 and acidic $\mathrm{pH}$, RCP 8.5 and alkaline $\mathrm{pH}$ ).

\subsection{Antimicrobial Resistance Profiles}

Climate change has been implicated as a factor involved in increasing levels of antimicrobial resistance among different bacterial species in prolonged temporal sets. Distinct spatial patterns occur globally and are connected with local climacteric variability, highlighting how distinct geographical areas will be impacted by this problem in different proportions $[39,40]$. Specifically, regions expected to be more vulnerable to climacteric alterations are also the ones predicted to accumulate the highest prevalence of antimicrobial resistance [41]. Some authors report the role of increasing temperatures over time in the overexpression of this phenomenon in species such as Escherichia coli, Klebsiella pneumoniae, Pseudomonas aeruginosa and Staphylococcus aureus [40,42]. In a meta-analysis with isolates collected in aquacultures conducted by Reverter et al. [41], a similar conclusion was drawn for bacterial genera commonly infecting aquatic animals. In this study, we show that climatic scenarios of changing temperature and $\mathrm{pH}$ can alter the antimicrobial susceptibility profile of different Aeromonas species. Although species belonging to the Aeromonas genus are normally resistant to erythromycin and susceptible to tetracycline and sulfamethoxazole/trimethoprim, the selected strains in this study displayed variable susceptibility status to these antimicrobials; however, and with the exception of one strain (A. hydrophila and tetracycline), reversion of the original susceptibility status occurred for all tested strains and antimicrobial compounds at least in one experimental condition.

In some situations, reversion of non-susceptibility to susceptibility to the tested antimicrobial compounds was observed. Antibiotic resistance represents a fitness cost for bacterial species and the development of resistance is modulated by this parameter $[43,44]$. 
Resistance to antimicrobial compounds can impact important cellular activities or be met with higher energetic costs related to gene expression needs [45,46]. Thus, when experiencing amplified fitness costs, such as those provided by changes in temperature and $\mathrm{pH}$, the rate of resistance reversibility in bacteria increases [43]. In this study, it seems that several combinations of water temperature and $\mathrm{pH}$ treatments resulted in the phenomenon that accommodates this hypothesis; however, resistance development was also observed in this study for strains displaying wild-type status. In alternative to resistance acquisition through horizontal gene transfer, a process known to be modulated by temperature conditions [42], de novo mutations (including recombination) can explain antibiotic resistance development in the absence of resistance determinants or antimicrobial pressure in the environment $[45,46]$, as in this study. In fact, increasing temperatures have been associated with genome-wide selection of these mutations [47]. Despite the costs in fitness already described for resistance acquisition, bacterial species have the potential to downplay such costs by means of compensatory evolution by developing mutations that will decrease fitness cost without compromising antimicrobial resistance or by performing physiological adaptations or activating specific systems that buffer mutational effects and fitness costs $[45,46,48,49]$. Different factors can influence the acquisition of antibiotic resistance in these settings, such as thermal stress or changes in $\mathrm{pH}[50,51]$. Antimicrobial resistance development occurred in this study for several combinations of water temperature and $\mathrm{pH}$ treatments. It is likely that the final antimicrobial susceptibility of the isolates corresponds to an "arms race" between external stressors impact, fitness costs and genetic adaptation by the bacteria, unraveling a non-linear relationship between the tested variables and the antimicrobial susceptibility of Aeromonas spp.

\section{Materials and Methods}

\subsection{Strain Selection}

Aeromonas species selection followed results obtained prior to this study [52]. Namely, the occurrence of mesophilic Aeromonas spp. was investigated in Iberochondrostoma lusitanicum in four freshwater streams in the Lisbon district, Portugal (Lizandro: 38.886701 ${ }^{\circ}$, $-9.298140^{\circ}$; Samarra: $38.894761^{\circ},-9.433734^{\circ}$; Jamor: $38.720832^{\circ},-9.249696^{\circ}$; Laje: $38.709159^{\circ}$, $-9.314079^{\circ}$ ) previously characterized by our team [53]. A. caviae, A. hydrophila, A. media and $A$. veronii were considered the most abundant species and, hence, included in this study. Strains were selected from a bacterial library evaluated by a RAPD (random amplified polymorphic DNA) technique in order to perform molecular typing and genomic differentiation. Three isolates of each Aeromonas species that were not considered clones, originating from different locations, were selected as representatives for inclusion in the study $(n=12)$.

The strains' ability to produce slime was evaluated using a phenotypical assay, Congo Red Agar $\left(22^{\circ} \mathrm{C}, 72 \mathrm{~h}\right)$, as described before [54]. Only slime-producer strains were selected for inclusion in the study.

Strains were stored in pure cultures in cryovials stored at $-80^{\circ} \mathrm{C}$. Prior to their use, resuscitation was performed by transferring $100 \mu \mathrm{L}$ of each bacterial suspension to $8 \mathrm{~mL}$ of Brain Heart Infusion broth (BHIB; VWR, Radnor, PA, USA), incubating for $24 \mathrm{~h}$ at $21^{\circ} \mathrm{C}$. After, bacterial suspensions were transferred to solid mediums-BHI agar and Columbia Blood (COS) agar (Biomérieux, Marcy-l'Étoile, France)—and incubated at $21^{\circ} \mathrm{C}$ for $24 \mathrm{~h}$. The purity of the cultures was confirmed by macro and microscopic morphology, as well as by Gram staining and phenotypic traits (oxidase production).

\subsection{Biofilm Formation Quantification}

In order to standardize the number of colony-forming units (CFU) in the suspensions to be used in the quantification of biofilm formation, reference Aeromonas strains were selected, namely A. caviae ATCC 1976, A. hydrophila ATCC 7966, A. media ATCC 33907 and A. veronii ATCC 35624. 
Briefly, reference strains were incubated in BHI agar and COS agar at $21^{\circ} \mathrm{C}$ for $24 \mathrm{~h}$. After incubation, for each reference strain, colonies were selected and inoculated in $5 \mathrm{~mL}$ of $0.9 \%$ saline solution until adjusting to a turbidity of 0.5 McFarland using a digital densitometer DENSIMAT (Biomérieux, Marcy-l'Étoile, France). After homogenization, serial ten-fold dilutions were performed in $9 \mathrm{~mL}$ of $0.9 \%$ saline solution (up to $10^{-6}$ ). From each dilution $\left(10^{-4}\right.$ to $\left.10^{-6}\right), 100 \mu \mathrm{L}$ were collected and plated in BHI agar in duplicate, using sterilized glass beads. Plates were incubated at $21^{\circ} \mathrm{C}$ up to $48 \mathrm{~h}$. Colonies were counted in both plates and averaged. The number of CFU/mL was calculated using the formula (number of colonies $\times$ dilution factor)/volume.

Biofilm formation was performed using the microtiter plate assay and quantification was performed using the crystal violet method, as described before $[55,56]$ with modifications. Bacterial colonies were collected from BHI agar and suspended in $5 \mathrm{~mL}$ of $0.9 \%$ saline solution until adjusting to a turbidity of $0.5 \mathrm{McF}$ arland. Based on the pre-established average CFU/mL for each Aeromonas species, concentrations were adjusted for each strain in order to prepare a final concentration in the wells of the Nunc ${ }^{\mathrm{TM}}$ MicroWell $^{\mathrm{TM}}$ 96-well plates (ThermoFisher Scientific ${ }^{\circledR}$, Waltham, MA, USA) of $5 \times 10^{5} \mathrm{UFC} / \mathrm{mL}$ in a final volume of $200 \mu \mathrm{L}$. As culture medium, Tryptic Soy Broth (TSB, VWR, Radnor, PA, USA) supplemented with $0.25 \%$ glucose (Millipore ${ }^{\circledR}$, Merck, Darmstadt, Germany) was used. A. hydrophila ATCC 7966 is considered a strong biofilm producer; hence it was selected as a positive control. As a negative control, TSB supplemented with $0.25 \%$ glucose was used in six wells in each assay. The microtiter plate was incubated at $21^{\circ} \mathrm{C}$ for $48 \mathrm{~h}$.

After incubation, the content of all wells was carefully aspirated to eliminate planktonic forms and the wells were washed three times at room temperature with phosphatebuffered saline (PBS; VWR, Radnor, PA, USA) at pH 7.0. The PBS was discarded after the final wash and the microtiter plate was incubated in an inverted position at $60{ }^{\circ} \mathrm{C}$ for $1 \mathrm{~h}$, for the adherent cells to fixate. After, $150 \mu \mathrm{L}$ of $0.25 \%$ Hucker crystal violet (diluted in de-ionized water; Merck, Darmstadt, Germany) were added to the wells, followed by incubation at room temperature for $5 \mathrm{~min}$. The stain excess was aspirated, and the microtiter plate rinsed until the rinse was free of stain. The microtiter plate was airdried at room temperature and, once dry, $150 \mu \mathrm{L}$ of $95 \%$ ethanol (NORMAPUR ${ }^{\circledR}$, VWR, Radnor, PA, USA) were added to each well for solubilization of the stain. The microtiter plate was covered with the lid to avoid ethanol's evaporation and incubated at room temperature for $30 \mathrm{~min}$. After incubation, the optical density (OD) of the microtiter plate was evaluated at $570 \mathrm{~nm}$ in a horizontal bidirectional reading using the FLUOstar OPTIMA microplate reader (BMG LABTECH, Ortenberg, Germany). This assay was performed prior and after the microcosm assay to enable further comparisons. In both situations, three replicates were performed for each strain on independent days.

\subsection{Antimicrobial Susceptibility Testing}

Antimicrobial susceptibility testing was performed using the disk diffusion technique [57]. Guidelines of the Clinical and Laboratory Standards Institute for Aeromonas salmonicida testing were followed as reference [58], selected since the testing temperature$22{ }^{\circ} \mathrm{C}$-closely resembles the temperature used for the basal treatment. The following antibiotics (Mastdiscs ${ }^{\circledR}$, Mast Group, Liverpool, UK) were tested: erythromycin (E, $\left.15 \mu \mathrm{g}\right)$, tetracycline $(\mathrm{T}, 30 \mu \mathrm{g})$ and sulfamethoxazole/trimethoprim (TS, 23.75-1.25 $\mu \mathrm{g})$. Antimicrobial compound choice followed options where epidemiological cut-off values were available. A "wild-type" (WT) phenotype implies isolate susceptibility to the antimicrobial, while a "non-wild-type" (NWT) phenotype implies that the isolate presents resistance mechanisms. Escherichia coli ATCC 25922 was used as a quality control. This technique was performed prior and after the microcosm assay to enable further comparisons. One strain from each species was randomly selected to be tested. Only strains from pure culture microcosms (i.e., no strains from mixed cultures microcosms were used) were used to perform the antimicrobial susceptibility testing. The same strain was used prior and 
after microcosm comparisons. In both situations, $10 \%$ of replicates were performed on independent days.

\subsection{Microcosm Assay}

To evaluate the influence that water temperature and $\mathrm{pH}$ might have in the antimicrobial resistance and virulence profiles of Aeromonas spp., a microcosm simulation assay was developed. Testing variables (i.e., temperature and $\mathrm{pH}$ ) were selected based on the expected impact that climatic alterations will have in these two parameters in freshwater ecosystems [5] and on the known influence of these variables on bacterial biofilm formation and resistance acquisition/expression [42,59-62].

Regarding water temperature, four experimental conditions were used. First, a condition representing the current water temperature values was created based on trends in water temperature observed during higher temperature months (July to October) in the Lisbon's District rivers (Cascais, Oeiras and Sintra municipalities) in the period between 1985-2016 and averaged $\left(21^{\circ} \mathrm{C}\right)$ [63]. Only sampling points located far from the river mouth were selected to prevent temperature oscillations related to other water bodies. Similarly, only sampling points with substantial datasets over a wide temporal frame were selected $(n=6)$. Location was selected to match the origin of the bacterial isolates. Additionally, two different 21st-century projections of climate alterations for the period of 2081-2100 establishing different levels of greenhouse gas emissions and atmospheric conditions, air pollutant emissions and land use were selected-representative concentration pathways (RCP) 4.5 , representing a scenario of medium stabilization $\left(23.2^{\circ} \mathrm{C}\right)$ and 8.5 , representing a scenario of high warming $\left(24.5^{\circ} \mathrm{C}\right)$ [5]. To mimic a scenario of rapid temperature fluctuations, the protocol established by Saarinen, Lindström and Ketola [22] was implemented with modifications to accommodate Aeromonas spp. growth conditions and the temperature ranges defined for this study. So, repetitions of $24 \mathrm{~h}$ cycles of either $24.5^{\circ} \mathrm{C}$ or $21^{\circ} \mathrm{C}$ were applied. Additionally, to establish an initial time point to enable comparisons in both the microtiter plate assay and the disk diffusion technique prior and after the microcosm assays, a treatment (T0) mimicking the current water temperature and $\mathrm{pH}\left(21^{\circ} \mathrm{C}, \mathrm{pH} 7.61\right)$ was included. Contrarily to the other treatments, the strains in $\mathrm{T} 0$ were incubated in river water for only $24 \mathrm{~h}$.

Simulations from van Vliet et al. [7] on the correlation between air and river water temperature were used to determine final water temperature conditions for the RCP scenarios. Additionally, river discharge level, which also affects water temperature, was based on simulations by van Vliet et al. [7,14] for the Iberian Peninsula and fixed at decrease levels of $40 \%$.

Regarding water $\mathrm{pH}$, and since this parameter trends in rivers will vary according to demographic and geologic characteristics of the areas adjacent to the river $[64,65]$, both a scenario of acidification and a scenario of alkalization were included. Three conditions were created, two mimicking both previously described scenarios and one establishing the current water $\mathrm{pH}$ conditions. Water $\mathrm{pH}$ values were established based on trends accessed in the same datasets used for temperature [63]. The treatment established as the current condition was based on the average of the values recorded in the analyzed period ( $\mathrm{pH}$ 7.61). The acidification scenario was based on the average of the lowest $\mathrm{pH}$ values observed in all analyzed rivers ( $\mathrm{pH}$ 6.31), while the alkalization scenario was based on the average of the highest $\mathrm{pH}$ values recorded $(\mathrm{pH}$ 8.61). A summary of the experimental conditions used in this study is found in Table 1.

Microcosm experimental setup was adapted from Zhang and Buckling [66] and Cairns et al. [67]. Water preparation was performed as described in Sautour et al. [33]. BHIB was used as an addictive of river's water to act as a nutrient source. This medium was used at a $2.5 \%$ concentration to resemble the resource levels found in natural ecosystems.

Briefly, river water collected in a freshwater stream in the Lisbon district (Jamor: $38.720832^{\circ},-9.249696^{\circ}$ ) was filtered using a $0.22 \mu \mathrm{m}$ Millipore filter (Frilabo, Maia, Portugal) and autoclaved at $121^{\circ} \mathrm{C}$ for $20 \mathrm{~min}$. For each water $\mathrm{pH}$ condition, BHIB was added to 
the water and $\mathrm{pH}$ adjusted to match the conditions established using a HI-4521 Research Grade pH/ORP/EC Bench Meter (Hanna Instruments, Póvoa de Varzim, Portugal). Bacterial suspensions were prepared by collecting colonies from BHI agar that were suspended in $5 \mathrm{~mL}$ of $0.9 \%$ saline solution until achieving a turbidity of $0.5 \mathrm{McF}$ arland. Suspensions were prepared in pure cultures and in mixed cultures (with only one strain of each speciesA. caviae, A. hydrophila, A. media and A. veronii-represented once). Nunc ${ }^{\mathrm{TM}}$ MicroWell $^{\mathrm{TM}}$ 96-well plates were used to establish the microcosm. In pure culture wells, $200 \mu \mathrm{L}$ of the respective medium were added, following the addition of $10 \mu \mathrm{L}$ of the bacterial suspension. In the mixed culture wells, $2.5 \mu \mathrm{L}$ of each bacterial strain was used. In both situations, bacterial suspensions were prepared in $0.9 \%$ saline solution previously according to the established average $\mathrm{CFU} / \mathrm{mL}$ of the reference strains to achieve a final concentration of $5 \times 10^{5} \mathrm{UFC} / \mathrm{mL}$ in each well. In the negative control wells, $210 \mu \mathrm{L}$ of the respective medium was added. Plates were incubated for 6 days in the respective temperature treatment inside an SSI10 SSI10-2 orbital shaking incubator (Shel Lab, Cornelius, NC, USA) at $150 \mathrm{rpm}$ to mimic water turbulence in the natural habitat. Every $48 \mathrm{~h}$ of incubation, renewal of the medium was performed by adding $20 \mu \mathrm{L}$ of the previous culture into a new plate with $180 \mu \mathrm{L}$ of the respective medium. At the end of each microcosm assay, the OD was read at $570 \mathrm{~nm}$ as described before to determine bacterial growth. After reading, $10 \mu \mathrm{L}$ from each well was transferred into BHI agar, incubated at the respective assay's temperature for $24 \mathrm{~h}$ and used for biofilm quantification, antimicrobial susceptibility testing and species confirmation (in the case of the mixed culture wells). The $\mathrm{pH}$ values for each assay were validated by randomly selecting bacterial cultures across the three different $\mathrm{pH}$ used, as well as the negative controls mediums, and analyzed using Neutralit ${ }^{\circledR} \mathrm{pH}$-indicator paper (Merck, Darmstadt, Germany). Tests were performed immediately after incubation.

Table 1. Experimental conditions used in the microcosm assays. RCP-representative concentration pathway.

\begin{tabular}{cccc}
\hline \multicolumn{5}{c}{ Experimental Conditions } \\
\hline Temperature $\left({ }^{\circ} \mathbf{C}\right)$ & & $\mathbf{p H}$ \\
\hline Current & 21 & Current & 7.61 \\
RCP 4.5 & 23.2 & Acidification & 6.31 \\
RCP 8.5 & 24.5 & Alkalization & 8.61 \\
Fluctuations & $21-24.5$ & & \\
\hline
\end{tabular}

\subsection{Aeromonas Species Confirmation in Mixed Culture Wells}

Following the microcosm assays, species confirmation in the mixed culture wells was performed. Bacterial colonies with distinct macroscopic morphology in $\mathrm{BHI}$ agar were selected and streaked into pure cultures. The purity of the cultures was evaluated by macro and microscopic analysis, and Gram staining and oxidase production were evaluated.

Bacterial genomic DNA was obtained by the boiling method [68]. To achieve species identification, a multiplex PCR protocol previously described [69] was used with some modifications. This protocol targets the identification of the four species included in this study. A. caviae ATCC 1976, A. hydrophila ATCC 7966, A. media ATCC 33907 and A. veronii ATCC 35624 were used as positive controls.

Briefly, PCR mixtures were performed in a final volume of $25 \mu \mathrm{L}$, composed of: $12.15 \mu \mathrm{L}$ of Supreme NZYTaq $2 \times$ Green Master Mix (NZYTech, Lisbon, Portugal), $10 \mu \mathrm{L}$ of PCR-grade water (Sigma-Aldrich, Saint Louis, MO, USA), $0.025 \mu \mathrm{L}(0.05 \mu \mathrm{M})$ of primers A-16s, $0.25 \mu \mathrm{L}(0.5 \mu \mathrm{M})$ of primers A-cav, $0.1 \mu \mathrm{L}(0.2 \mu \mathrm{M})$ of primers A-med, $0.225 \mu \mathrm{L}$ $(0.45 \mu \mathrm{M})$ of primers A-hyd, $0.075 \mu \mathrm{L}(0.15 \mu \mathrm{M})$ of primers A-Ver; and $1.5 \mu \mathrm{L}$ of template DNA. Thermocycler conditions included a hot start at $95^{\circ} \mathrm{C}$ for $2 \mathrm{~min}$; followed by 6 cycles of denaturation at $94{ }^{\circ} \mathrm{C}$ for $40 \mathrm{~s}$, annealing at $68^{\circ} \mathrm{C}$ for $50 \mathrm{~s}$ and extension at $72{ }^{\circ} \mathrm{C}$ for $40 \mathrm{~s}$; and 30 cycles at $94{ }^{\circ} \mathrm{C}$ for $40 \mathrm{~s}, 66^{\circ} \mathrm{C}$ for $50 \mathrm{~s}$ and $72{ }^{\circ} \mathrm{C}$ for $40 \mathrm{~s}$. 
Amplification products were resolved by gel electrophoresis using $1.5 \%(w / v)$ agarose in $1 \times$ TBE Buffer (NZYTech, Lisbon, Portugal). Gels were resolved for $45 \mathrm{~min}$ at $90 \mathrm{~V}$ and NZYDNA Ladder VI (NZYTech, Lisbon, Portugal) was used as a molecular weight marker. Gels were visualized using a UV light transilluminator. The images were recorded through the Bio-Rad ChemiDoc XRS imaging system (Bio-Rad Laboratories, Hercules, CA, USA).

\subsection{Statistical Analysis}

Prior to statistical analysis, the influence of the microcosm assay (i.e., other factors than the water temperature and $\mathrm{pH}$ conditions) on the biofilm production and antimicrobial resistance profiles was accessed by comparing the results obtained with the treatment T0 and current $\mathrm{pH} 7.61$ (similar water temperature and $\mathrm{pH}$ conditions). A coefficient of variation of $25 \%$ was set as a breakpoint and calculated individually for each Aeromonas species. Minimal and maximal limits were calculated regarding T0 values. Current $\mathrm{pH}$ 7.61 values that fell outside the limit were considered significantly different. Replicates of isolates where this situation occurred were excluded from the subsequent analysis due to possible bias (i.e., A. veronii \#1 3rd replicate, mixed culture \#1 2nd and 3rd replicates, mixed culture \#2 2nd replicate, mixed culture \#3 1st and 2 nd replicates). For antimicrobial resistance profiles, a qualitative comparison of the epidemiological cut-off values between the two treatments was performed and no deviations occurred.

Several isolate level response variables were analyzed regarding temperature and $\mathrm{pH}$ treatments. Using a factorial ANOVA where it was determined the difference in values regarding T0 treatment and Tukey's multiple comparison test to evaluate differences between treatments, the (1) biofilm production and the (2) bacterial growth were considered. Using a stepwise linear regression and a point-biserial correlation, the influence of the different Aeromonas species in mixed cultures on the production of biofilm was considered. Pearson's correlation was calculated between biofilm production and bacterial growth. The statistical analysis was performed using IBM SPSS Statistics version 27 software (IBM Analytics, New York, NY, USA). Graphs were produced using GraphPad Prism ${ }^{\circledR}$ (GraphPad Software, San Diego, CA, USA, version 5.01).

\section{Conclusions}

Current results show how Aeromonas spp. will respond to projected environmental shifts in water temperature and $\mathrm{pH}$. Namely, that temperature increments will have a biphasic effect on Aeromonas spp. growth, while this bacterial genus will multiply better in acidic environments. Further, Aeromonas spp. biofilm production will be decreased due to temperature oscillations and microbial interactions in mixed cultures. Finally, antimicrobial resistance signatures of Aeromonas spp. will vary individually to changing temperature and $\mathrm{pH}$ parameters. Although general patterns were observed, it is evident that modulation of the intrinsic bacterial characteristics varies across isolates and that the final expression pattern will be influenced by environmental drivers and individual variability; however, the general patterns determined with this study deepen our knowledge on bacterial alterations expected in aquatic environments, strengthening our awareness and response to future bacterial outbreaks and how to deal with them.

Simplification of experimental settings, such as the approach applied in this study, has the limitation of disregarding the role of many other biotic and abiotic factors that can play a role in bacterial growth and virulence and resistance expression. Additionally, focusing on one bacterial genus to study such interactions is a major limitation of this study, since it fails to represent both the outcomes of a bacterial community that closely resembles natural communities, as well as beneficial and detrimental effects of distinct bacterial strains/species on a particular bacterial strain in focus. Further development of microcosm experiments to accommodate more complex networks of drivers and bacterial communities is required. 
Author Contributions: Conceptualization, M.L.G., C.S.-S., J.I.R. and M.O.; methodology, M.L.G., A.P., C.S.-S., J.I.R. and M.O.; software, M.L.G. and A.P.; validation, M.L.G. and A.P.; formal analysis, M.L.G. and A.P.; investigation, M.L.G.; resources, M.L.G. and M.O.; data curation, M.L.G. and A.P.; writing—original draft preparation, M.L.G.; writing—review and editing, M.L.G., A.P., C.S.-S., J.I.R. and M.O.; visualization, M.L.G.; supervision, J.I.R. and M.O.; project administration, M.O.; funding acquisition, M.L.G., J.I.R. and M.O. All authors have read and agreed to the published version of the manuscript.

Funding: This research was supported by CIISA-Centro de Investigação Interdisciplinar em Sanidade Animal, Faculdade de Medicina Veterinária, Universidade de Lisboa, Project UIDB/00276/2020 (funded by FCT—Fundação para a Ciência e Tecnologia IP) and by MARE (MARE-ISPA), MARE/UIDB/MAR/04292/2020 and strategic project MARE/UIDP/MAR/04292/2020 (also funded by FCT). MLG thanks funding by the University of Lisbon (PhD fellowship C10571K).

Acknowledgments: The authors wish to thank Eva Cunha and Maria de Fátima Santos (FMVULisboa) for their assistance during laboratory work.

Conflicts of Interest: The authors declare no conflict of interest. The funders had no role in the design of the study; in the collection, analyses, or interpretation of data; in the writing of the manuscript, or in the decision to publish the results.

\section{References}

1. Parter, M.; Kashtan, N.; Alon, U. Environmental variability and modularity of bacterial metabolic networks. BMC Evol. Biol. 2007, 7, 169. [CrossRef]

2. Ratzke, C.; Gore, J. Modifying and reacting to the environmental pH can drive bacterial interactions. PLoS Biol. 2018, 16, e2004248. [CrossRef]

3. De Silva, P.M.; Chong, P.; Fernando, D.M.; Westmacott, G.; Kumar, A. Effect of incubation temperature on antibiotic resistance and virulence factors of Acinetobacter baumannii ATCC 17978. Antimicrob. Agents Chemother. 2018, 62, e01514-17. [CrossRef]

4. Huang, L.; Liu, W.; Jiang, Q.; Zuo, Y.; Su, Y.; Zhao, L.; Qin, Y.; Yan, Q. Integration of transcriptomic and proteomic approaches reveals the temperature-dependent virulence of Pseudomonas plecoglossicida. Front. Cell. Infect. Microbiol. 2018, 8, 207. [CrossRef]

5. Pachauri, R.K.; Allen, M.R.; Barros, V.R.; Broome, J.; Cramer, W.; Christ, R.; Church, J.A.; Clarke, L.; Dahe, Q.; Dasgupta, P.; et al. Climate Change 2014: Synthesis Report. Contribution of Working Groups I, II and III to the Fifth Assessment Report of the Intergovernmental Panel on Climate Change; Pachauri, R., Meyer, L., Eds.; IPCC: Geneva, Switzerland, 2014; p. 151.

6. Knouft, J.H.; Ficklin, D. The potential impacts of climate change on biodiversity in flowing freshwater systems. Annu. Rev. Ecol. Evol. Syst. 2017, 48, 111-133. [CrossRef]

7. Van Vliet, M.T.H.; Ludwig, F.; Zwolsman, J.J.G.; Weedon, G.P.; Kabat, P. Global river temperatures and sensitivity to atmospheric warming and changes in river flow. Water Resour. Res. 2011, 47. [CrossRef]

8. Bucak, T.; Trolle, D.; Andersen, H.E.; Thodsen, H.; Erdoğan, S.; Levi, E.E.; Filiz, N.; Jeppesen, E.; Beklioğlu, M. Future water availability in the largest freshwater Mediterranean lake is at great risk as evidenced from simulations with the SWAT model. Sci. Total Environ. 2017, 581-582, 413-425. [CrossRef] [PubMed]

9. Griffith, A.W.; Gobler, C.J. Harmful algal blooms: A climate change co-stressor in marine and freshwater ecosystems. Harmful Algae 2020, 91, 101590. [CrossRef] [PubMed]

10. Kaushal, S.S.; Likens, G.E.; Pace, M.L.; Utz, R.; Haq, S.; Gorman, J.; Grese, M. Freshwater salinization syndrome on a continental scale. Proc. Natl. Acad. Sci. USA 2018, 115, E574-E583. [CrossRef]

11. Le, T.D.H.; Kattwinkel, M.; Schützenmeister, K.; Olson, J.R.; Hawkins, C.P.; Schäfer, R.B. Predicting current and future background ion concentrations in German surface water under climate change. Philos. Trans. R. Soc. B Biol. Sci. 2019, 374, 20180004. [CrossRef] [PubMed]

12. Dudgeon, D. Multiple threats imperil freshwater biodiversity in the Anthropocene. Curr. Biol. 2019, 29, R960-R967. [CrossRef]

13. Mosley, L. Drought impacts on the water quality of freshwater systems; review and integration. Earth Sci. Rev. 2015, 140, 203-214. [CrossRef]

14. Van Vliet, M.T.; Franssen, W.H.; Yearsley, J.R.; Ludwig, F.; Haddeland, I.; Lettenmaier, D.P.; Kabat, P. Global river discharge and water temperature under climate change. Glob. Environ. Chang. 2013, 23, 450-464. [CrossRef]

15. Pinceel, T.; Buschke, F.; Weckx, M.; Brendonck, L.; Vanschoenwinkel, B. Climate change jeopardizes the persistence of freshwater zooplankton by reducing both habitat suitability and demographic resilience. BMC Ecol. 2018, 18, 2. [CrossRef] [PubMed]

16. Rodell, M.; Famiglietti, J.; Wiese, D.N.; Reager, J.T.; Beaudoing, H.K.; Landerer, F.W.; Lo, M.-H. Emerging trends in global freshwater availability. Nature 2018, 557, 651-659. [CrossRef] [PubMed]

17. Chen, H.; Jing, L.; Teng, Y.; Wang, J. Characterization of antibiotics in a large-scale river system of China: Occurrence pattern, spatiotemporal distribution and environmental risks. Sci. Total Environ. 2018, 618, 409-418. [CrossRef] [PubMed]

18. Peterson, E.; Kaur, P. Antibiotic resistance mechanisms in bacteria: Relationships between resistance determinants of antibiotic producers, environmental bacteria, and clinical pathogens. Front. Microbiol. 2018, 9, 2928. [CrossRef] [PubMed] 
19. Alexander, J.; Bollmann, A.; Seitz, W.; Schwartz, T. Microbiological characterization of aquatic microbiomes targeting taxonomical marker genes and antibiotic resistance genes of opportunistic bacteria. Sci. Total Environ. 2015, 512-513, 316-325. [CrossRef] [PubMed]

20. Dias, M.F.; da Rocha Fernandes, G.; de Paiva, M.C.; Salim, A.C.D.M.; Santos, A.B.; Nascimento, A.M.A. Exploring the resistome, virulome and microbiome of drinking water in environmental and clinical settings. Water Res. 2020, 174, 115630. [CrossRef]

21. Friman, V.-P.; Hiltunen, T.; Jalasvuori, M.; Lindstedt, C.; Laanto, E.; Örmälä, A.-M.; Laakso, J.; Mappes, J.; Bamford, J.K.H. High Temperature and bacteriophages can indirectly select for bacterial pathogenicity in environmental reservoirs. PLoS ONE 2011, 6, e17651. [CrossRef] [PubMed]

22. Saarinen, K.; Lindström, L.; Ketola, T. Invasion triple trouble: Environmental fluctuations, fluctuation-adapted invaders and fluctuation-mal-adapted communities all govern invasion success. BMC Evol. Biol. 2019, 19, 42. [CrossRef] [PubMed]

23. Abbott, S.L.; Cheung, W.K.; Janda, J.M. The genus aeromonas: Biochemical characteristics, atypical reactions, and phenotypic identification schemes. J. Clin. Microbiol. 2003, 41, 2348-2357. [CrossRef] [PubMed]

24. Wang, Y.; Gu, J. Influence of temperature, salinity and $\mathrm{pH}$ on the growth of environmental Aeromonas and Vibrio species isolated from Mai Po and the Inner Deep Bay Nature Reserve Ramsar Site of Hong Kong. J. Basic Microbiol. 2005, 45, 83-93. [CrossRef] [PubMed]

25. Awan, F.; Dong, Y.; Wang, N.; Liu, J.; Ma, K.; Liu, Y. The fight for invincibility: Environmental stress response mechanisms and Aeromonas hydrophila. Microb. Pathog. 2018, 116, 135-145. [CrossRef]

26. Thomas, L.V.; Wimpenny, J.W. Competition between Salmonella and Pseudomonas species growing in and on agar, as affected by $\mathrm{pH}$, sodium chloride concentration and temperature. Int. J. Food Microbiol. 1996, 29, 361-370. [CrossRef]

27. Lopez-Vazquez, C.M.; Oehmen, A.; Hooijmans, C.M.; Brdjanovic, D.; Gijzen, H.J.; Yuan, Z.; van Loosdrecht, M.C. Modeling the PAO-GAO competition: Effects of carbon source, $\mathrm{pH}$ and temperature. Water Res. 2009, 43, 450-462. [CrossRef] [PubMed]

28. Yuan, S.; Meng, F. Ecological insights into the underlying evolutionary patterns of biofilm formation from biological wastewater treatment systems: Red or black queen hypothesis? Biotechnol. Bioeng. 2020, 117, 1270-1280. [CrossRef]

29. Delamare, A.P.L.; Costa, S.O.P.; Da Silveira, M.M.; Echeverrigaray, S. Growth of Aeromonas species on increasing concentrations of sodium chloride. Lett. Appl. Microbiol. 2000, 30, 57-60. [CrossRef]

30. Nana, G.Y.G.; Ripoll, C.; Cabin-Flaman, A.; Gibouin, D.; Delaune, A.; Janniere, L.; Grancher, G.; Chagny, G.; Loutelier-Bourhis, C.; Lentzen, E.; et al. Division-based, growth rate diversity in bacteria. Front. Microbiol. 2018, 9, 849. [CrossRef]

31. Goelzer, A.; Fromion, V. Bacterial growth rate reflects a bottleneck in resource allocation. Biochim. Biophys. Acta 2011, 1810, 978-988. [CrossRef]

32. Cavari, B.Z.; Allen, D.; Colwell, R.R. Effect of temperature on growth and activity of Aeromonas spp. and mixed bacterial populations in the Anacostia river. Appl. Environ. Microbiol. 1981, 41, 1052-1054. [CrossRef]

33. Sautour, M.; Mary, P.; Chihib, N.; Hornez, J. The effects of temperature, water activity and pH on the growth of Aeromonas hydrophila and on its subsequent survival in microcosm water. J. Appl. Microbiol. 2003, 95, 807-813. [CrossRef] [PubMed]

34. Palumbo, S.A.; Morgan, D.R.; Buchanan, R.L. Influence of temperature, NaCI, and pH on the growth of Aeromonas hydrophila. J. Food Sci. 1985, 50, 1417-1421. [CrossRef]

35. Knøchel, S. Growth characteristics of motile Aeromonas spp. isolated from different environments. Int. J. Food Microbiol. 1990, 10, 235-244. [CrossRef]

36. Vivekanandhan, G.; Savithamani, K.; Lakshmanaperumalsamy, P. Influence of $\mathrm{pH}$, salt concentration and temperature on the growth of Aeromonas hydrophila. J. Environ. Biol. 2003, 24, 373-379. [PubMed]

37. Karem, K.L.; Foster, J.W.; Bej, A.K. Adaptive acid tolerance response (ATR) in Aeromonas hydrophila. Microbiology 1994, 140, 1731-1736. [CrossRef]

38. Buncic, S.; Avery, S.M. Effect of pre-incubation $\mathrm{pH}$ on the growth characteristics of Aeromonas hydrophila at $5^{\circ} \mathrm{C}$, as assessed by two methods. Lett. Appl. Microbiol. 1995, 20, 7-10. [CrossRef]

39. Alvarez-Uria, G.; Midde, M. Trends and factors associated with antimicrobial resistance of Acinetobacter spp. invasive isolates in Europe: A country-level analysis. J. Glob. Antimicrob. Resist. 2018, 14, 29-32. [CrossRef] [PubMed]

40. Kaba, H.E.; Kuhlmann, E.; Scheithauer, S. Thinking outside the box: Association of antimicrobial resistance with climate warming in Europe-A 30 country observational study. Int. J. Hyg. Environ. Health 2020, 223, 151-158. [CrossRef]

41. Reverter, M.; Sarter, S.; Caruso, D.; Avarre, J.-C.; Combe, M.; Pepey, E.; Pouyaud, L.; Vega-Heredía, S.; De Verdal, H.; Gozlan, R.E. Aquaculture at the crossroads of global warming and antimicrobial resistance. Nat. Commun. 2020, 11, 70. [CrossRef]

42. MacFadden, D.R.; McGough, S.F.; Fisman, D.; Santillana, M.; Brownstein, J.S. Antibiotic resistance increases with local temperature. Nat. Clim. Chang. 2018, 8, 510-514. [CrossRef] [PubMed]

43. Andersson, D.I.; Hughes, D. Antibiotic resistance and its cost: Is it possible to reverse resistance? Nat. Rev. Microbiol. 2010, 8 , 260-271. [CrossRef]

44. Sundqvist, M. Reversibility of antibiotic resistance. Upsala J. Med Sci. 2014, 119, 142-148. [CrossRef]

45. Melnyk, A.H.; Wong, A.; Kassen, R. The fitness costs of antibiotic resistance mutations. Evol. Appl. 2015, 8, 273-283. [CrossRef]

46. Hernando-Amado, S.; Sanz-García, F.; Blanco, P.; Martínez, J.L. Fitness costs associated with the acquisition of antibiotic resistance. Essays Biochem. 2017, 61, 37-48. [CrossRef] [PubMed]

47. Berger, D.; Stångberg, J.; Baur, J.; Walters, R.J. Elevated temperature increases genome-wide selection on de novo mutations. Proc. R. Soc. B 2021, 288, 20203094. [CrossRef] [PubMed] 
48. Freihofer, P.; Akbergenov, R.; Teo, Y.; Juskeviciene, R.; Andersson, D.I.; Böttger, E.C. Nonmutational compensation of the fitness cost of antibiotic resistance in mycobacteria by overexpression of tlyA rRNA methylase. RNA 2016, 22, 1836-1843. [CrossRef] [PubMed]

49. Fay, A.; Philip, J.; Saha, P.; Hendrickson, R.C.; Glickman, M.S.; Burns-Huang, K. The DnaK chaperone system buffers the fitness cost of antibiotic resistance mutations in mycobacteria. mBio 2021, 12, e00123-21. [CrossRef] [PubMed]

50. McMahon, M.A.S.; Xu, J.; Moore, J.E.; Blair, I.S.; McDowell, D.A. Environmental stress and antibiotic resistance in food-related pathogens. Appl. Environ. Microbiol. 2007, 73, 211-217. [CrossRef]

51. Rodríguez-Verdugo, A.; Gaut, B.S.; Tenaillon, O. Evolution of Escherichia coli rifampicin resistance in an antibiotic-free environment during thermal stress. BMC Evol. Biol. 2013, 13, 50. [CrossRef]

52. Grilo, M.; Isidoro, S.; Chambel, L.; Marques, C.; Marques, T.; Sousa-Santos, C.; Robalo, J.; Oliveira, M. Molecular epidemiology, virulence traits and antimicrobial resistance signatures of Aeromonas spp. in the critically endangered Iberochondrostoma lusitanicum follow geographical and seasonal patterns. Antibiotics 2021, 10, 759. [CrossRef]

53. Sousa-Santos, C.; Robalo, J.I.; Pereira, A.M.; Branco, P.; Santos, J.M.; Ferreira, M.T.; Sousa, M.; Doadrio, I. Broad-scale sampling of primary freshwater fish populations reveals the role of intrinsic traits, inter-basin connectivity, drainage area and latitude on shaping contemporary patterns of genetic diversity. PeerJ 2016, 4, e1694. [CrossRef] [PubMed]

54. Freeman, D.J.; Falkiner, F.R.; Keane, C.T. New method for detecting slime production by coagulase negative staphylococci. J. Clin. Pathol. 1989, 42, 872-874. [CrossRef] [PubMed]

55. Stepanović, S.; Vuković, D.; Dakić, I.; Savić, B.; Švabić-Vlahović, M. A modified microtiter-plate test for quantification of staphylococcal biofilm formation. J. Microbiol. Methods 2000, 40, 175-179. [CrossRef]

56. Stepanović, S.; Vukovic, D.; Hola, V.; Di Bonaventura, G.; Djukić, S.; Ćirković, I.; Ruzicka, F. Quantification of biofilm in microtiter plates: Overview of testing conditions and practical recommendations for assessment of biofilm production by staphylococci. APMIS 2007, 115, 891-899. [CrossRef]

57. Bauer, A.W.; Kirby, W.M.; Sherris, J.C.; Turck, M. Antibiotic susceptibility testing by a standardized single disk method. Am. J. Clin. Pathol. 1966, 45, 493-496. [CrossRef] [PubMed]

58. Clinical and Laboratory Standards Institute-CLSI. Performance Standards for Antimicrobial Susceptibility Testing of Bacteria Isolated From Aquatic Animals; 2nd Informational Supplement; CLSI document VET03/VET04-S2; Clinical and Laboratory Standards Institute: Wayne, PA, USA, 2014.

59. Goller, C.C.; Romeo, T. Environmental influences on biofilm development. In Bacterial biofilms. Current Topics in Microbiology and Immunology; Romeo, T., Ed.; Springer: Berlin, Germany, 2008; p. 322.

60. Toyofuku, M.; Inaba, T.; Kiyokawa, T.; Obana, N.; Yawata, Y.; Nomura, N. Environmental factors that shape biofilm formation. Biosci. Biotechnol. Biochem. 2016, 80, 7-12. [CrossRef]

61. Cruz-Loya, M.; Kang, T.M.; Lozano, N.A.; Watanabe, R.; Tekin, E.; Damoiseaux, R.; Savage, V.M.; Yeh, P.J. Stressor interaction networks suggest antibiotic resistance co-opted from stress responses to temperature. ISME J. 2018, 13, 12-23. [CrossRef]

62. Mueller, E.; Egan, A.J.; Breukink, E.; Vollmer, W.; Levin, P.A. Plasticity of Escherichia coli cell wall metabolism promotes fitness and antibiotic resistance across environmental conditions. eLife 2019, 8, e40754. [CrossRef]

63. SNIRH. Sistema Nacional de Informação de Recursos Hídricos. 2021. Available online: https://snirh.apambiente.pt/index.php? idMain=2\&idItem=1 (accessed on 22 June 2020). (In Portuguese)

64. Kaushal, S.S.; Likens, G.E.; Utz, R.M.; Pace, M.L.; Grese, M.; Yepsen, M. Increased river alkalinization in the Eastern U.S. Environ. Sci. Technol. 2013, 47, 10302-10311. [CrossRef]

65. Oberholster, P.; Botha, A.-M.; Hill, L.; Strydom, W. River catchment responses to anthropogenic acidification in relationship with sewage effluent: An ecotoxicology screening application. Chemosphere 2017, 189, 407-417. [CrossRef]

66. Zhang, Q.-G.; Buckling, A. Phages limit the evolution of bacterial antibiotic resistance in experimental microcosms. Evol. Appl. 2012, 5, 575-582. [CrossRef] [PubMed]

67. Cairns, J.; Becks, L.; Jalasvuori, M.; Hiltunen, T. Sublethal streptomycin concentrations and lytic bacteriophage together promote resistance evolution. Philos. Trans. R. Soc. B 2017, 372, 20160040. [CrossRef] [PubMed]

68. Talon, D.; Mulin, B.; Thouverez, M. Clonal identification of Aeromonas hydrophila strains using randomly amplified polymorphic DNA analysis. Eur. J. Epidemiol. 1998, 14, 305-310. [CrossRef]

69. Persson, S.; Al-Shuweli, S.; Yapici, S.; Jensen, J.N.; Olsen, K.E.P. Identification of clinical Aeromonas species by rpoB and gyrb sequencing and development of a multiplex PCR method for detection of Aeromonas hydrophila, A. caviae, A. veronii, and A. media. J. Clin. Microbiol. 2014, 53, 653-656. [CrossRef] [PubMed] 